\title{
Research on the Relationship between Industrial Structure Evolution and Industry Income Gap in Hong Kong
}

\author{
Yi Jin \\ School of Economics, Jinan University, Guangzhou, China \\ Email: christinajy@163.com
}

How to cite this paper: Jin, Y. (2018) Research on the Relationship between Industrial Structure Evolution and Industry Income Gap in Hong Kong. Modern Economy, 9, 682-698.

https://doi.org/10.4236/me.2018.94044

Received: March 21, 2018

Accepted: April 21, 2018

Published: April 24, 2018

Copyright $\odot 2018$ by author and Scientific Research Publishing Inc. This work is licensed under the Creative Commons Attribution International License (CC BY 4.0).

http://creativecommons.org/licenses/by/4.0/

\begin{abstract}
The widening industry income gap in Hong Kong has seriously hindered the balanced development of industry and sustained and healthy economic growth. Therefore, it is of great significance to explore the influence mechanism of industrial structure evolution on industry income gap and the relationship between them. This paper takes Hong Kong's industrial structure evolution and industry income gap as the research object, and comprehensively uses statistical data and census data to analyze in detail the causal relationship between industrial structure evolution and industry income gap. Starting with the evolution of Hong Kong's industrial structure, this paper follows the idea that the industrial structure determines the employment structure and thus affects the change of the industry income gap. Then we use agent variables which describe the nature of industrial structure evolution and industry income gap to conduct causality analysis and regression analysis to find the dynamic and quantitative relationship between them.
\end{abstract}

\section{Keywords}

Industrial Structure Evolution, Industry Income Gap, Hong Kong, Relationship Research

\section{Introduction}

Since its opening in 1841, Hong Kong has completed the transition from the "traditional economy" to the "industrial economy" to the "service economy". Since the reunification, although Hong Kong has suffered a series of external shocks such as the Asian financial crisis, SARS and the US subprime mortgage crisis, which have hit its economic growth to a certain extent, the actual economic growth has remained at a relatively high level. And it has gradually 
formed a trade logistics industry, financial services, professional and producer support services and tourism as the pillar industries of the economic structure. In twenty-first century, Hong Kong's economy was once in a downturn, but it soon started a new turn to the "knowledge-based economy". In order to promote the diversification of the local industrial structure, the Hong Kong SAR Government has identified six industries which have obvious advantages in Hong Kong and have potential for further development. At the present stage, the economic development of Hong Kong has shown a good situation in general and is the freest economy in the world. As a developed economy, Hong Kong has long been in the top 10 in the global competitiveness index released by the world economic forum. In the latest 2017-2018 ranking, Hong Kong ranks sixth above Japan [1].

With the rapid economic growth, the income gap of Hong Kong has been expanding. It has formed a coexistence of rapid economic growth and widening income gap. The gap between the rich and the poor in Hong Kong has not changed much since the reunification. Its Gini coefficient has always been a high level in developed countries or regions and has remained above 0.5 for a long time, and the distribution of income has not improved with the economic growth. Although the minimum wage policy has raised the income of low paid workers, the situation of in-service poverty in Hong Kong is still very serious, and the income distribution gap between industries is widening. There is a problem of the coordination and interaction mechanism between economic development and social stability. In the context of service-oriented industrial structure in Hong Kong, this study chooses to start with the evolution of industrial structure in Hong Kong, following the idea that industrial structure determines the employment structure and then affects the change of industry income gap. This paper attempts to study the relationship between the evolution of Hong Kong's industrial structure and industry income gap.

This paper is organized as follows. Firstly, this paper reviews the relevant research literature. Then this paper clarifies the relationship between industrial structure evolution and employment structure and the change of industry income gap caused by employment structure. Furthermore, we empirically analyze the relationship between industrial structure evolution and industry income gap in Hong Kong. Finally, the conclusion of this paper is drawn.

The main contribution of this paper is to discuss in detail the relationship between industrial structure evolution and industry income gap in Hong Kong, and to provide a new way of thinking for the study of industry income gap. It also proves that there is a progressive mechanism and causality between industrial structure evolution and industry income gap in Hong Kong, which provides a visual angle for Hong Kong to study how to narrow the industry income gap. Due to the limitations of individual academic level and data acquisition, this paper has the following shortcoming. There is no systematic theoretical model for the transmission mechanism of industrial structure and employment structure and industry income gap in Hong Kong, which is not convincing enough, which 
is expected to continue to research and improve in the future. This is expected to improve in future research.

\section{Literature Review}

\subsection{Research on Industrial Structure Evolution in Hong Kong}

With the development of Hong Kong's economy and society, the research on the evolution of industrial structure in Hong Kong is gradually deepened, and the main studies are as follows.

Liu Guofen (2006) points out that the evolution of Hong Kong's industrial structure is divided into four stages: 1) Before 1950s, Hong Kong is in a period of economic recovery and dominant re-export trade; 2) From the 1950s to the 1970s, it is the period of industrialization in Hong Kong; 3) From the 1970s to the 1980s, it is the period of industrial diversification and service industry growth in Hong Kong; 4) Since 1980s, the manufacturing industry of Hong Kong has moved northward and its industrial structure has been highly light. At this time, the proportion of manufacturing industry has decreased, and the proportion of service industry has increased substantially. Hong Kong has a distinct characteristic of service economy. Liu Guofen further points out that Hong Kong has four characteristics related to the industrial structure from the point of view of the actual economic situation. First, the industrial structure has not developed towards diversification, and become more service-oriented. Second, the growth of the service industry is mainly driven by non-productive service industry. Third, CEPA's zero tariff policy and "free travel" policy have little effect on stimulating industrial investment. Fourth, the problem of structural unemployment in Hong Kong is serious [2].

Feng Bangyan (2015) sums up the economic development and the industrial structure evolution in Hong Kong into three stages: 1) The period from 1951 to 1980 is the period of Hong Kong's economic industrialization; 2) From 1980 to 1997, Hong Kong's economic structure is service-oriented; 3) From 1997 to now, Hong Kong is in the stage of becoming a global financial center and improving the strategic position of the three major centers, namely, the international financial center, the international trade center and the shipping center [3].

Guo Jiang and Jing Yan (2016) point out that after the transformation of Hong Kong into a service-oriented economy, the tertiary industry has continued to expand, while the fact that the secondary industry dominated by manufacturing has continued to shrink. And by comparing the industrial structure of Singapore, it is revealed that the unbalance of the industrial structure caused by the low proportion of Hong Kong's manufacturing industry is an important reason for its weak of economic growth [4].

\subsection{Research on the Relationship between Industrial Structure Evolution and Industry Income Gap in Hong Kong}

In the study of the relationship between industrial structure evolution and in- 
come gap in Hong Kong, some scholars have done a positive study.

Zhang Yingwu (2007) calculates the degree of industrial deviation and concludes that industries that are related to the future development of Hong Kong are all negative industrial structure deviation, such as import and export trade, finance and insurance, professional services and communication industry, as a result, the ability of these industries to absorb employment is very limited. He points out that the economic growth promoted by the export-oriented high value-added and efficient service industry in Hong Kong does not drive regional consumption and does not benefit lower class workers [5].

Chen Guanghan and Zhang Yingwu (2009) put forward that the influence of economic transformation through the employment market on personal income distribution is an important factor for the deterioration of income inequality in Hong Kong. On the one hand, the economic transformation results in the transfer of employment from the manufacturing industry with relatively low Gini coefficient to the service industry, especially the specialized service industry, where the Gini coefficient is relatively high. On the other hand, the economic transformation leads to the higher level of education for the employed, and the more dispersed income of the highly educated group leads to the increase of income inequality [6]. Gan Hongming (2012) notes that "de-industrialization" expands the income gap in Hong Kong in three ways: Firstly, Hong Kong's "de-industrialization" has caused massive structural unemployment and depressed the wage level of the middle and lower level labor force. Secondly, due to the failure to promote the upgrading of manufacturing industry, the channel for upgrading human capital has been blocked, which has led a large number of workers to switch to the service industry with low skill requirements, such as transportation, retail, household service industry etc. As a result, wage growth cannot keep up with the pace of economic development. Finally, the development of high value-added service industry makes a small number of people obtain huge returns on wealth investment, accelerate the speed of wealth concentration, and expand the degree of inequality in income distribution [7]. Guan Hongling (2014) points out that the industrial structure transformation leads to the widening of the income gap between industries in Hong Kong, and the income gap is expanding not only between industries, but also within the industry. It is pointed out that the small income gap in the industry is the construction industry [8].

\subsection{Brief Summary}

According to the foregoing, we know that some literatures have attached importance to the research of the evolution of Hong Kong's industrial structure and have done some research and analysis on the relationship between industrial structure evolution and industry income gap in Hong Kong. However, relevant literatures fail to explain the transmission mechanism of the effect of industrial structure evolution on the industrial income gap in Hong Kong, and there is no 
empirical analysis of the causal and quantitative relationship between the two. This paper studies these problems in the later text.

\section{Causal relationship between Industrial Structure Evolution and Industry Income Gap in Hong Kong}

\subsection{Research Ideas}

In the previous literature review, some scholars have analyzed the reasons for the widening of the income gap in Hong Kong from the perspective of industrial structure. The research ideas of this paper are as follows: there is a progressive mechanism between the evolution of industrial structure and the change of employment structure and the change of industry income gap. On the one hand, as the carrier of employment, the industrial sector determines the employment structure to a large extent. Therefore, the evolution of the industrial structure in Hong Kong will inevitably lead to corresponding changes in the employment structure, so that there is a reasonable employment structure corresponding to it [9]. On the other hand, due to the difference of wage levels among different industrial sectors, the employment structure greatly determines the income situation of the employment population and its family among the various industrial sectors. And the change or stability of the employment structure will directly affect the change of industry income gap in Hong Kong.

\subsection{The Relationship between Industrial Structure Evolution and Employment Structure in Hong Kong}

The evolution of industrial structure in Hong Kong shows two remarkable characteristics: one is the service-oriented industrial structure, the other is the specialization of the service industry. Accordingly, the employment structure of Hong Kong is also showing the characteristics of service-oriented and specialization.

According to Figure 1, from 1996 to 2016, the proportion of service added value to GDP in Hong Kong has always been higher than 85 percent. Compared with other non-service industries, the service industry occupies an absolute advantage. Accordingly, the proportion of employment in Hong Kong's service industry is much higher than that of other non-service sectors. Especially since this century, the two curves describing the proportion of the added value of the service industry to the GDP and the proportion of the employment of the service industry to the total employment have gradually tended to coincide. In 2016, the added value of service industry in Hong Kong accounted for 92.2 percent of GDP. In 2016, the added value of service industry in Hong Kong accounts for 92.2 percent of GDP, and the proportion of service employment to total employment is about 92.4 percent, which is slightly greater than the proportion of service industry added value to GDP. Consequently, Hong Kong is a service economy. The industrial structure tends to be service-oriented, which determines that Hong Kong's labor force is mainly concentrated in the service sector. 


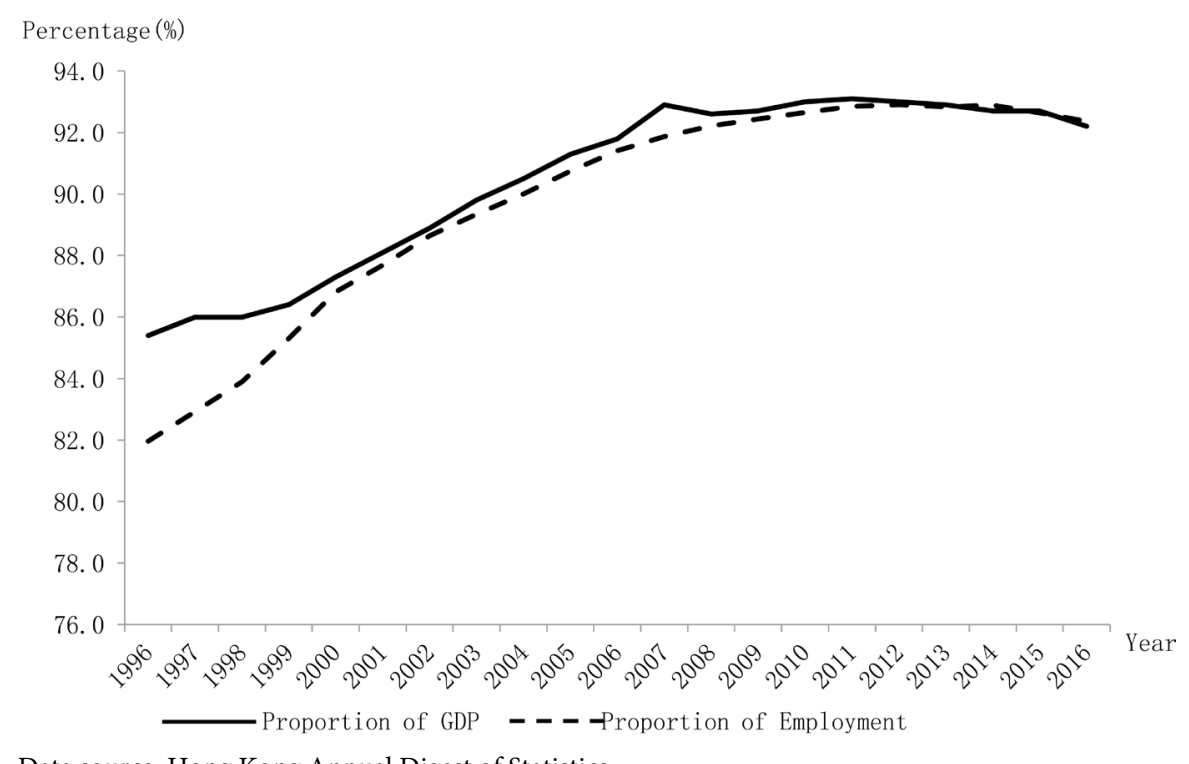

Data source: Hong Kong Annual Digest of Statistics.

Figure 1. 1996-2006 service industry GDP ratio (basic price calculation) and employment occupation ratio in Hong Kong (\%).

We further examine the development of specialization within the service industry. According to the Hong Kong Standard Industrial Classification version 2.0, we have classified the service industry (excluding ownership of premises) into three categories: productive service industry (including information and communications, financing and insurance, real estate, professional and business services), circulation service industry (including import/export, wholesale and retail trades, transportation, storage, postal and courier services) and living service industry (including accommodation and food services, society and personal services) [10] [11] [12].

According to the availability of data, as can be seen from Table 1, from 2000 to 2016, the three types of service industry in Hong Kong presents a noticeable regular change in two aspects of the proportion of GDP and the proportion of employment. Firstly, the proportion of the added value of the productive service industry to GDP and the employment proportion of the productive service industry are increasing, but the former is slightly higher than the latter. Secondly, the proportion of the value added to GDP in the circulation service industry and the living service industry is less than the proportion of their respective employment in the total employment. On the one hand, from 2000 to 2016, the proportion of value added in the circulation service industry to GDP has gone through a process of first rising and then decreasing, and it has decreased by 1.2 percentage points in total. The proportion of employment in the circulation service industry is declining in general, from $40.8 \%$ in 2000 to $35.1 \%$ in 2016 , and a total reduction of 5.7 percentage points. On the other hand, the proportion of living service industry added value to GDP has basically not changed, but its share of employment tends to increase, from $22 \%$ in 2000 to $28 \%$ in 2016 , a total increase of 6 percentage points. Thirdly, with the evolution of industrial structure, 
Table 1. 2000-2016 three types of service industry GDP ratio (basic price calculation) and employment occupation ratio in Hong Kong (\%).

\begin{tabular}{|c|c|c|c|c|c|c|}
\hline \multirow[b]{2}{*}{ Year } & \multicolumn{2}{|c|}{ Productive service industry } & \multicolumn{2}{|c|}{ Circulation service industry } & \multicolumn{2}{|c|}{ Living service industry } \\
\hline & $\begin{array}{c}\text { Proportion } \\
\text { of GDP }\end{array}$ & $\begin{array}{l}\text { Proportion of } \\
\text { employment }\end{array}$ & $\begin{array}{l}\text { Proportion } \\
\text { of GDP }\end{array}$ & $\begin{array}{l}\text { Proportion of } \\
\text { employment }\end{array}$ & $\begin{array}{l}\text { Proportion } \\
\text { of GDP }\end{array}$ & $\begin{array}{c}\text { Proportion of } \\
\text { employment }\end{array}$ \\
\hline 2000 & 25.3 & 24.1 & 29.2 & 40.8 & 21.9 & 22.0 \\
\hline 2001 & 24.4 & 24.5 & 29.6 & 40.2 & 22.8 & 23.0 \\
\hline 2002 & 24.5 & 24.7 & 30.6 & 40.3 & 22.7 & 23.6 \\
\hline 2003 & 25.4 & 24.8 & 31.4 & 40.6 & 22.4 & 23.9 \\
\hline 2004 & 25.2 & 25.1 & 33.5 & 40.5 & 22.1 & 24.4 \\
\hline 2005 & 26.0 & 25.4 & 34.5 & 40.5 & 20.7 & 24.9 \\
\hline 2006 & 28.7 & 25.9 & 32.8 & 40.1 & 19.9 & 25.4 \\
\hline 2007 & 32.5 & 26.5 & 31.1 & 39.7 & 19.3 & 25.7 \\
\hline 2008 & 30.4 & 26.9 & 30.7 & 39.4 & 20.5 & 26.0 \\
\hline 2009 & 30.2 & 27.2 & 29.7 & 38.6 & 21.3 & 26.6 \\
\hline 2010 & 30.3 & 27.6 & 31.7 & 38.3 & 20.2 & 26.8 \\
\hline 2011 & 30.7 & 28.3 & 32.2 & 37.5 & 20.0 & 27.0 \\
\hline 2012 & 30.9 & 28.7 & 31.4 & 37.0 & 20.4 & 27.2 \\
\hline 2013 & 30.9 & 29.0 & 31.0 & 36.6 & 20.6 & 27.3 \\
\hline 2014 & 31.1 & 29.0 & 30.3 & 36.2 & 20.8 & 27.7 \\
\hline 2015 & 32.0 & 29.2 & 29.2 & 35.5 & 20.9 & 27.9 \\
\hline 2016 & 32.2 & 29.3 & 28.0 & 35.1 & 21.4 & 28.0 \\
\hline
\end{tabular}

Data source: Census and Statistics Department (The Government of the Hong Kong Special Administrative Region).

the employment population in Hong Kong is flowing out of the circulation service industry, part of which flows to the living service industry, and the other part flows to the productive service industry. From the change of proportion, from 2000 to 2016, the proportion of the employment of the living service industry to total employment has increased by 6 percentage points, while the proportion of the employment of the productive service industry to total employment has increased by 5.2 percentage points, indicating that the former flow is slightly larger than the latter one.

\subsection{Employment Structure Leads to the Change of Industry Income Gap in Hong Kong}

First of all, we inspect the income gap between industries in Hong Kong. As shown in Table 2, the overall income of the productive service industry is the highest, and median monthly wages of its sub sectors from 2010 to 2016 are all more than HK $\$ 18,000$. The income of the circulation service industry is at the middle level, while the income level of the living service industry is generally 
Table 2. Median monthly wages divided by industry in Hong Kong (HK\$).

\begin{tabular}{|c|c|c|c|c|c|}
\hline & \multirow[b]{2}{*}{ Industry/Year } & \multirow[b]{2}{*}{2010} & \multirow[b]{2}{*}{2016} & \multicolumn{2}{|c|}{$2010-2016$} \\
\hline & & & & Average & $\begin{array}{l}\text { Added } \\
\text { value }\end{array}$ \\
\hline \multirow{4}{*}{$\begin{array}{l}\text { Productive service } \\
\text { industry }\end{array}$} & Information and communications & 15,000 & 20,700 & 18,043 & 5700 \\
\hline & Financing and insurance & 19,100 & 26,000 & 22,900 & 6900 \\
\hline & Real estate & 15,500 & 20,700 & 18,143 & 5200 \\
\hline & $\begin{array}{l}\text { Professional, scientific and } \\
\text { technical activities }\end{array}$ & 16,300 & 21,500 & 19,086 & 5200 \\
\hline \multirow{5}{*}{$\begin{array}{l}\text { Circulation service } \\
\text { industry }\end{array}$} & Import and export trade & 13,000 & 17,100 & 15,371 & 4100 \\
\hline & Wholesale & 10,400 & 13,800 & 12,186 & 3400 \\
\hline & Retail trades & 9,000 & 12,400 & 10,857 & 3400 \\
\hline & Land transportation & 12,500 & 17,500 & 15,014 & 5000 \\
\hline & $\begin{array}{l}\text { Other transportation, storage, postal and } \\
\text { courier services }\end{array}$ & 12,400 & 16,800 & 14,643 & 4400 \\
\hline \multirow{6}{*}{$\begin{array}{l}\text { Living service } \\
\text { industry }\end{array}$} & Food services & 8000 & 11,800 & 9971 & 3800 \\
\hline & Accommodation and other food services & 11,300 & 14,400 & 12,914 & 3100 \\
\hline & $\begin{array}{l}\text { Property management, security } \\
\text { and cleaning services }\end{array}$ & 7000 & 11,200 & 9471 & 4200 \\
\hline & Administrative and support services & 11,600 & 15,800 & 13,757 & 4200 \\
\hline & $\begin{array}{l}\text { Travel agents, booking services } \\
\text { and related activities }\end{array}$ & 9600 & 13,800 & 11,900 & 4200 \\
\hline & Miscellaneous activities & 7400 & 11,500 & 9,686 & 4100 \\
\hline Manufacturing & & 11,200 & 15,600 & 13,400 & 4400 \\
\hline Construction & & 13,700 & 21,200 & 17,443 & 7500 \\
\hline
\end{tabular}

Data source: Hong Kong Annual Digest of Statistics.

low. In each of the sub sectors, the median monthly wage of the financing and insurance is the highest, reaching $\mathrm{HK} \$ 26,000$ in 2016, while the median monthly wage of property management, security and cleaning services is the lowest, with only $\mathrm{HK} \$ 11,200$ in 2016 . It can be seen that the former is 2.3 times more than the latter. From the perspective of added value in income, in addition to construction, the added value of the median monthly wage in productive service industry is the largest. In productive service industry, from 2010 to 2016, the added value of the median monthly wage is HK $\$ 5200$ (real estate and professional, scientific and technical activities), and the highest added value of the median monthly wage is in the financing and insurance, and it has reached HK $\$ 6900$. The added value of the median monthly wage in the living service industry is generally low and added value of food services and accommodation and other food services is HK $\$ 3800$ and HK $\$ 3100$. The added value of the median monthly wage in the circulation service industry is in the middle. In addition to 
land transportation, added value in several other sub sectors is between HK $\$ 3400$ and HK $\$ 4400$. Thus, in the service industry, the income gap between the productive service industry and the living service industry and the circulation service industry is expanding.

We further examine the income gap between different types of occupation in Hong Kong. Referring to the practice of Guan Hongling (2014), according to the skill and monthly income level, this paper divides the employed population of Hong Kong into upper, middle and lower classes. The classification is shown in the following Table 3 [8].

We then study the income gap between different occupations and classes in Hong Kong, as shown in Table 4.

1) The income gap between different occupations is obvious. In all occupations, in 2016, the largest median monthly income is the managers and administrators, which is HK $\$ 43,000$. The second is professionals, and the median monthly income is $\mathrm{HK} \$ 36,000$. The lowest income is elementary occupations with a median monthly income of only HK $\$ 7000$. It is worth noting that elementary occupations account for the largest proportion of employment, reaching $20.9 \%$.

From the change of income, although the income of all occupations is increasing, the difference is significant. From 1996 to 2016, the largest increase in the median monthly income is the managers and administrators, with an increase of $115 \%$. The second is the craft and related workers, which the median monthly income increases by $76 \%$. The smallest increase in the median monthly income is the elementary occupations, with an increase of only $27 \%$. The growth of other occupations is more than $50 \%$.

2) The structure of the three classes of employment personnel in Hong Kong has changed from "spindle shaped" to "dumbbell shaped". In 1996, the proportion of employed persons in the upper, middle and lower classes is $29.2 \%, 37.6 \%$

Table 3. Class by occupation in Hong Kong.

\begin{tabular}{|c|c|c|c|}
\hline Occupation & Class division & Level of skill & $\begin{array}{c}\text { Monthly } \\
\text { income level }\end{array}$ \\
\hline \multicolumn{4}{|l|}{ Managers and administrators } \\
\hline Professionals & $\begin{array}{c}\text { Upper-level } \\
\text { employment staff }\end{array}$ & High & $\begin{array}{c}\text { Higher than } \\
\text { average income }\end{array}$ \\
\hline \multicolumn{4}{|l|}{ Associate professionals } \\
\hline \multicolumn{4}{|l|}{ Clerical support workers } \\
\hline Craft and related workers & $\begin{array}{l}\text { Middle-level } \\
\text { employment staff }\end{array}$ & Middle & $\begin{array}{c}\text { Close to average } \\
\text { income }\end{array}$ \\
\hline \multicolumn{4}{|l|}{ Plant and machine operators and assemblers } \\
\hline \multicolumn{4}{|l|}{ Service and sales workers } \\
\hline $\begin{array}{l}\text { Elementary occupations } \\
\text { Skilled agricultural and fishery workers; and } \\
\text { occupations not classifiable }\end{array}$ & $\begin{array}{c}\text { Lower-level } \\
\text { employment staff }\end{array}$ & Low & $\begin{array}{c}\text { Lower than } \\
\text { average income }\end{array}$ \\
\hline
\end{tabular}


Table 4. Median monthly income (HK\$) and proportion of employment (\%) by occupation in Hong Kong.

\begin{tabular}{|c|c|c|c|c|c|c|c|c|c|c|}
\hline Year & & 1996 & & 001 & & 006 & & 2011 & & 016 \\
\hline Occupation & $\begin{array}{l}\text { Median } \\
\text { monthly } \\
\text { Income }\end{array}$ & $\begin{array}{l}\text { Proportion } \\
\text { of } \\
\text { employment }\end{array}$ & $\begin{array}{l}\text { Median } \\
\text { monthly } \\
\text { Income }\end{array}$ & $\begin{array}{l}\text { Proportion } \\
\text { of } \\
\text { employment }\end{array}$ & $\begin{array}{l}\text { Median } \\
\text { monthly } \\
\text { Income }\end{array}$ & $\begin{array}{l}\text { Proportion } \\
\text { of } \\
\text { employment }\end{array}$ & $\begin{array}{l}\text { Median } \\
\text { monthly } \\
\text { Income }\end{array}$ & $\begin{array}{c}\text { Proportion } \\
\text { of } \\
\text { employment }\end{array}$ & $\begin{array}{l}\text { Median } \\
\text { monthly } \\
\text { Income }\end{array}$ & $\begin{array}{l}\text { Proportion } \\
\text { of } \\
\text { employment }\end{array}$ \\
\hline $\begin{array}{l}\text { Managers and } \\
\text { administrators }\end{array}$ & 20,000 & 12.1 & 26,000 & 10.7 & 26,000 & 10.8 & 36,250 & 10.1 & 43,000 & 10.1 \\
\hline Professionals & 24,000 & 5.0 & 30,000 & 5.5 & 25,000 & 6.1 & 32,160 & 6.5 & 36,000 & 7.0 \\
\hline $\begin{array}{c}\text { Associate } \\
\text { professionals }\end{array}$ & 14,000 & 12.1 & 16,000 & 15.3 & 15,000 & 16.1 & 18,000 & 19.6 & 21,250 & 20.5 \\
\hline $\begin{array}{l}\text { Clerical support } \\
\text { workers }\end{array}$ & 9000 & 16.8 & 10,000 & 16.3 & 9500 & 16.9 & 10,000 & 15.6 & 14,000 & 14.1 \\
\hline $\begin{array}{c}\text { Craft and related } \\
\text { workers }\end{array}$ & 8500 & 12.3 & 10,000 & 9.9 & 10,000 & 8.5 & 10,500 & 7.4 & 15,000 & 5.6 \\
\hline $\begin{array}{c}\text { Plant and machine } \\
\text { operators and } \\
\text { assemblers }\end{array}$ & 8500 & 8.5 & 10,000 & 7.3 & 9500 & 6.2 & 10,000 & 5.0 & 13,000 & 4.3 \\
\hline $\begin{array}{l}\text { Service and sales } \\
\text { workers }\end{array}$ & 8500 & 13.8 & 9110 & 15.0 & 8500 & 16.4 & 9000 & 16.2 & 12,000 & 17.2 \\
\hline $\begin{array}{l}\text { Elementary } \\
\text { occupations }\end{array}$ & 5500 & 18.6 & 5300 & 19.5 & 4900 & 18.8 & 5000 & 19.5 & 7000 & 20.9 \\
\hline $\begin{array}{c}\text { Skilled agricultural } \\
\text { and fishery workers; } \\
\text { and occupations not } \\
\text { classifiable }\end{array}$ & 7000 & 0.8 & 7000 & 0.3 & 6500 & 0.3 & 7200 & 0.1 & 11,000 & 0.1 \\
\hline $\begin{array}{c}\text { Upper-level } \\
\text { employment staff }\end{array}$ & & 29.2 & & 31.7 & & 33.0 & & 36.2 & & 37.6 \\
\hline $\begin{array}{c}\text { Middle-level } \\
\text { employment staff }\end{array}$ & & 37.6 & & 33.5 & & 31.6 & & 28.0 & & 24.0 \\
\hline $\begin{array}{l}\text { Lower-level } \\
\text { employment staff }\end{array}$ & & 33.2 & & 34.8 & & 35.4 & & 35.8 & & 38.4 \\
\hline
\end{tabular}

Data source: 2006 Population By-census-Thematic Report: Household Income Distribution in Hong Kong. 2016 Population By-census-Thematic Report: Household Income Distribution in Hong Kong.

and $33.2 \%$ respectively. However, by the year of 2016, the proportion of employees in the upper, middle and lower classes has become $37.6 \%, 24.0 \%$ and 38.4\% respectively. Among them, from 1996 to 2016, the upper-level employment staff has increased by 8.4 percentage points, and the lower-level employment staff has increased by 5.2 percentage points, while the middle-level employment staff has decreased by 13.6 percentage points, and the reduction rate is very large.

According to the available data, we look at the Gini coefficient in Hong Kong in 2016 according to the industry classification. According to Table 5, in 2016, the Gini coefficient of Hong Kong's financing and insurance and real estate, professional and business services (calculated by the monthly major occupational income) ranks first and second in all industries. The Gini coefficient of the 
Table 5. 2016 Gini coefficient by industry in Hong Kong (calculated by the monthly major occupational income).

\begin{tabular}{cc}
\hline Industry/Year & 2016 \\
Manufacturing & 0.437 \\
Construction & 0.374 \\
Import/export, wholesale and retail trades & 0.471 \\
Transportation, storage, postal and courier services & 0.365 \\
Accommodation and food services & 0.361 \\
Information and communications & 0.407 \\
Financing and insurance & 0.516 \\
Real estate, professional and business services & 0.497 \\
Public administration, education, human health care and social work activities & 0.451 \\
Miscellaneous society and personal services & 0.373 \\
Others & 0.488 \\
Total & 0.495 \\
\hline
\end{tabular}

Notes: 1) Figures in this table are compiled based on the industry classification modeled on the Hong Kong Standard Industrial Classification Version 2.0. 2) Figures exclude unpaid family workers. 3) "Others" include "Agriculture and fishing"; "Mining and quarrying"; "Electricity and gas supply"; "Water supply, sewerage, waste management and remediation activities" and industrial activities inadequately described or unclassifiable. Data source: 2006 Population By-census-Thematic Report: Household Income Distribution in Hong Kong.

financing and insurance is 0.516 , and the Gini coefficient of the real estate, professional and business services is 0.497 . The increasing proportion of financing and insurance and real estate, professional and business services of total output value of service industry indicate that there is an increase in specialization within the service industry, which will result in a widening of the income gap in the industry.

In summary, it is not difficult to find that the polarization trend of the industry income gap in Hong Kong is increasing. It is particularly noteworthy that the differences in human capital between industries lead to differences in wage levels in industries. The high skilled labor force is concentrated in the high-income productive service industry, and the opportunity for the low skilled labor to flow upwards has been reduced due to the "threshold effect", which has led to a continuous reduction in the proportion of the middle-level employment staff, and a considerable number of labor forces are "stranded" in the lower levels. Because the income growth of the lower-level employment staff is obviously lagging behind the upper-level employment staff, the income gap in Hong Kong society continues to expand.

\section{Empirical Analysis}

This paper has already analyzed the evolution of Hong Kong's industrial structure and employment structure and analyzed the changes of industry income 
gap caused by employment structure from the perspective of industry, profession and class. This part attempts to further empirically analyze the relationship between industrial structure evolution and industry income gap in Hong Kong.

\subsection{Data}

Generally, we use the Theil index and Gini coefficient to measure the industry income gap. Referring to the relevant literature, this paper attempts to establish the following Theil index to measure the industry income gap in Hong Kong.

$$
T H=\frac{1}{n} \sum_{i=1}^{n} \frac{y_{i}}{\bar{y}} \ln \left(\frac{y_{i}}{\bar{y}}\right)
$$

In model (1), $T H$ is the Theil index to measure the industry income gap. $y_{i}$ represents the income of the industry $i . \bar{y}$ represents the average income of all industries [13].

Based on the availability of data, this paper selects the average wages of workers in various industries in Hong Kong from 1997 to 2015 to calculate the Theil index (Table 6). Due to the adjustment of industry items in Hong Kong in 2009,

Table 6. 1997-2015 average wages by industry in Hong Kong (HK\$).

\begin{tabular}{|c|c|c|c|c|c|}
\hline \multicolumn{2}{|c|}{ Year/Industry Manufacturing } & \multirow{2}{*}{$\begin{array}{c}\text { Wholesale, retail, import and export } \\
\text { trade, food and hotel industry } \\
11,468\end{array}$} & \multirow{2}{*}{$\begin{array}{c}\text { Transport service } \\
\text { industry }\end{array}$} & \multirow{2}{*}{$\begin{array}{c}\text { Financing, insurance, real estate } \\
\text { and business services }\end{array}$} & \multirow{2}{*}{$\begin{array}{c}\begin{array}{c}\text { Personal service } \\
\text { industry }\end{array} \\
6672\end{array}$} \\
\hline 1997 & 9,361 & & & & \\
\hline 1998 & 9691 & 11,783 & 13,595 & 11,247 & 7158 \\
\hline 1999 & 9689 & 11,802 & 13,471 & 11,671 & 6978 \\
\hline 2000 & 9748 & 11,960 & 12,932 & 11,442 & 7107 \\
\hline 2001 & 10,112 & 12,047 & 13,171 & 11,280 & 6638 \\
\hline 2002 & 9654 & 11,745 & 13,300 & 10,586 & 6364 \\
\hline 2003 & 9457 & 11,580 & 12,972 & 10,649 & 6163 \\
\hline 2004 & 9546 & 11,388 & 12,721 & 9855 & 6227 \\
\hline 2005 & 8816 & 11,707 & 13,193 & 9831 & 6061 \\
\hline 2006 & 9698 & 11,905 & 12,930 & 10,253 & 6167 \\
\hline 2007 & 10,109 & 11,921 & 13,154 & 11,206 & 6755 \\
\hline 2008 & 10,107 & 12,036 & 13,806 & 10,832 & 6738 \\
\hline 2009 & 9465 & 11,439 & 14,682 & 10,961 & 11,536 \\
\hline 2010 & 9415 & 11,813 & 14,882 & 11,438 & 12,108 \\
\hline 2011 & 10,790 & 12,883 & 15,663 & 12,305 & 12,925 \\
\hline 2012 & 11,566 & 13,446 & 16,283 & 13,215 & 14,546 \\
\hline 2013 & 12,439 & 14,281 & 16,843 & 13,677 & 15,009 \\
\hline 2014 & 12,986 & 14,708 & 17,756 & 14,260 & 15,889 \\
\hline 2015 & 13,416 & 15,211 & 18,832 & 14,804 & 17,402 \\
\hline
\end{tabular}

Notes: 1) The industry classification is compiled according to the Hong Kong Standard Industrial Classification Version 1.1. 2) The data from 2009 to 2015 are summarized according to industry classification. 3) Statistical data are quarterly averages. Data source: Census and Statistics Department (The Government of the Hong Kong Special Administrative Region). 
this paper combines the different industry categories in different periods and calculates the Theil index of industry income in different years. In this paper, the proportion of service added value to GDP is used to measure the service-oriented of industrial structure, and it is recorded as TR (Table 7). In order to further depict the effect of the change of industrial structure, we measure the internal specialization of service industry by using the proportion of output value of financing, insurance, real estate and business services in the service industry, and record it as TS (Table 8).

\subsection{Granger Causality Test}

The results of the study have passed the ADF unit root test, showing that $\mathrm{TH}$, TR and TS are all first-order single integer sequence, which can be used for causality test and cointegration analysis. Then we deal with the data in the Tables 6-8 and use the empirical calculation to get the results of Table 9. In the second period of lag, under the confidence level of 5\%, TR and TS are the Granger causes of

Table 7. 1997-2015 service industry added value and GDP in Hong Kong (Millions $\mathrm{HK} \$$ ).

\begin{tabular}{|c|c|c|}
\hline Year & Service industry & GDP \\
\hline 1997 & $1,136,366$ & $1,320,886$ \\
\hline 1998 & $1,082,657$ & $1,259,318$ \\
\hline 1999 & $1,066,525$ & $1,234,742$ \\
\hline 2000 & $1,120,265$ & $1,283,035$ \\
\hline 2001 & $1,118,884$ & $1,269,989$ \\
\hline 2002 & $1,110,646$ & $1,249,781$ \\
\hline 2003 & $1,102,221$ & $1,227,056$ \\
\hline 2004 & $1,163,558$ & $1,285,324$ \\
\hline 2005 & $1,257,617$ & $1,378,002$ \\
\hline 2006 & $1,352,383$ & $1,473,535$ \\
\hline 2007 & $1,490,475$ & $1,605,245$ \\
\hline 2008 & $1,499,529$ & $1,620,013$ \\
\hline 2009 & $1,466,724$ & $1,581,824$ \\
\hline 2010 & $1,614,922$ & $1,737,298$ \\
\hline 2011 & $1,770,166$ & $1,901,049$ \\
\hline 2012 & $1,872,498$ & $2,013,038$ \\
\hline 2013 & $1,948,292$ & $2,098,080$ \\
\hline 2014 & $2,044,750$ & $2,205,972$ \\
\hline 2015 & $2,154,603$ & $2,325,505$ \\
\hline
\end{tabular}

Notes: The data from 1997 to 1999 are compiled according to the Hong Kong Standard Industrial Classification Version 1.1. And the data from 2000 to 2015 are compiled according to the Hong Kong Standard Industrial Classification Version 2.0. Data source: Census and Statistics Department (The Government of the Hong Kong Special Administrative Region). 
Table 8. 1997-2015 value added in sub industry of service industry based on basic price in Hong Kong (Millions HK\$).

\begin{tabular}{|c|c|c|c|c|c|c|}
\hline Year/Industry & $\begin{array}{l}\text { Import and } \\
\text { export trade }\end{array}$ & $\begin{array}{l}\text { Wholesale and } \\
\text { retail trades }\end{array}$ & $\begin{array}{l}\text { Accommodation } \\
\text { and food services }\end{array}$ & $\begin{array}{l}\text { Transportation, storage, } \\
\text { postal and courier services }\end{array}$ & $\begin{array}{l}\text { Financing, insurance, } \\
\text { real estate and business services }\end{array}$ & $\begin{array}{l}\text { Community, social } \\
\text { and personal services }\end{array}$ \\
\hline 1997 & 223,264 & 51,088 & 43,297 & 114,358 & 327,316 & 234,979 \\
\hline 1998 & 216,052 & 41,683 & 35,528 & 108,849 & 288,693 & 246,865 \\
\hline 1999 & 209,045 & 41,801 & 35,682 & 108,994 & 270,968 & 256,603 \\
\hline 2000 & 234,643 & 42,334 & 37,843 & 140,469 & 282,443 & 243,423 \\
\hline 2001 & 239,075 & 42,723 & 34,449 & 138,542 & 265,218 & 255,543 \\
\hline 2002 & 244,691 & 39,658 & 30,949 & 143,115 & 260,236 & 252,581 \\
\hline 2003 & 252,850 & 36,737 & 26,505 & 140,411 & 266,576 & 247,694 \\
\hline 2004 & 274,545 & 46,283 & 34,128 & 151,461 & 281,911 & 249,018 \\
\hline 2005 & 310,065 & 49,666 & 37,494 & 161,254 & 312,077 & 247,942 \\
\hline 2006 & 313,361 & 53,206 & 42,701 & 165,245 & 374,639 & 251,211 \\
\hline 2007 & 324,571 & 54,895 & 48,830 & 171,413 & 469,983 & 262,395 \\
\hline 2008 & 337,170 & 62,029 & 53,600 & 147,517 & 443,198 & 278,100 \\
\hline 2009 & 309,773 & 60,453 & 48,789 & 147,101 & 429,803 & 288,109 \\
\hline 2010 & 341,615 & 71,693 & 56,418 & 192,965 & 472,228 & 295,257 \\
\hline 2011 & 401,558 & 91,342 & 66,421 & 182,986 & 519,269 & 313,585 \\
\hline 2012 & 410,071 & 101,466 & 72,044 & 191,475 & 551,728 & 337,678 \\
\hline 2013 & 413,445 & 110,296 & 75,413 & 201,610 & 572,037 & 356,326 \\
\hline 2014 & 421,004 & 110,538 & 78,725 & 215,419 & 607,423 & 379,588 \\
\hline 2015 & 420,046 & 107,776 & 78,134 & 230,886 & 662,647 & 407,467 \\
\hline
\end{tabular}

Data source: Census and Statistics Department (The Government of the Hong Kong Special Administrative Region).

Table 9. The result of granger causality test of industrial structure evolution and industry income gap (lag period: 2).

\begin{tabular}{cccc}
\hline Null Hypothesis & F-statistic & Prob. & Conclusion \\
TR does not Granger Cause TH & 9.41051 & $0.0035^{\star *}$ & 0.1810 \\
TH does not Granger Cause TR & 1.97772 & $0.0148^{* *}$ & $0.7093 \quad$ Reject Null Hypothesis \\
TS does not Granger Cause TH & 6.10444 & 0.35355 & Accept Null Hypothesis \\
TH does not Granger Cause TS &
\end{tabular}

Notes: ${ }^{*}$ represents that causal relationship exists at the significance level of 0.05 .

$\mathrm{TH}$, but TH is not the Granger reason of TR and TS, that is, the service industry structure is the Granger cause of the industry income gap, and the internal specialization of the service industry is the Granger cause of the income gap in the industry. That is to say, the service-oriented of the industrial structure is the Granger cause of industry income gap and the internal specialization of the service industry is also the Granger cause of industry income gap. This indicates that industrial structure evolution has a significant impact on the industry income gap in Hong Kong, which can be analyzed by regression analysis [14]. 


\subsection{Johansen Co-Integration Test}

According the result of Granger causality test (Table 9), the service-oriented of the industrial structure and the internal specialization of the service industry are Granger causes of industry income gap. We use the Theil index of the industry income gap (TH) as an explained variable, and we take two indices of the service-oriented of industrial structure (TR) and the internal specialization of service industry (TS) as explanatory variables. Then the time trend item (trend) is added, and the cointegration analysis is carried out to further explore the numerical relationship between industrial structure evolution and industry income gap in Hong Kong. We set up a cointegration regression model (model (2)). That is to say, the proportion of service added value to GDP and the proportion of output value of financing, insurance, real estate and business services in the service industry explain the change of the industry income gap.

$$
T H_{t}=\alpha_{t}+\beta T R_{t}+\gamma T S_{t}+\lambda T R E N D_{t}+\mu_{t}
$$

This paper selects average wages by industry, the changes of service industry added value and GDP and the value added in sub industry of service industry from 1997 to 2015 in Hong Kong are used to calculate the industry income gap Theil index, the service-oriented industrial structure index and the service internal specialization index respectively. The cointegration equation results are shown in Table 10 .

According to the results of Table 10, the estimated function can be written as follows.

$$
\begin{array}{ccc}
\widehat{T H}_{t} & =-0.8774+0.9955 T R_{t}+0.1526 T S_{t} & -0.0057 T_{R E N D_{t}} \\
\mathrm{z} & (-10.16) & (-1.95)
\end{array}
$$

The whole cointegration equation is significant, and TR and TS have passed $\mathrm{z}$ test

\begin{tabular}{|c|c|c|c|c|c|c|}
\hline \multicolumn{4}{|c|}{ Cointegrating equations } & & & \\
\hline Equation & Parms & $\mathrm{chi}^{2}$ & $\mathrm{P}>\mathrm{chi}^{2}$ & & & \\
\hline _ce1 & 2 & 111.2678 & 0.0000 & & & \\
\hline \multicolumn{7}{|c|}{ Identification: beta is exactly identified } \\
\hline \multicolumn{7}{|c|}{ Johansen normalization restriction imposed } \\
\hline beta & Coef. & Std. Err. & $\mathrm{z}$ & $\mathrm{p}>|\mathrm{z}|$ & 95\% Conf. & Interval \\
\hline \multicolumn{7}{|l|}{ _ce1 } \\
\hline th & 1 & . & . & . & . & . \\
\hline $\operatorname{tr}$ & -0.9954872 & 0.0979364 & -10.16 & 0.000 & -1.187439 & -0.8035353 \\
\hline ts & -0.1526207 & 0.0783512 & -1.95 & 0.051 & -0.3061862 & 0.0009447 \\
\hline _trend & 0.0057077 & . & . & . & . & . \\
\hline _cons & 0.8774314 & . & . & . & . & . \\
\hline
\end{tabular}
at the significance level of $10 \%$. The regression results show that the service-oriented

Table 10. Cointegration equation results. 
of industrial structure and the internal specialization of service industry are the reasons for the change of industry income gap. TR and TH, as well as TS and $\mathrm{TH}$, are positively related. This indicates that service-oriented development of industrial structure and internal specialization of service industry can lead to the widening of industry income gap in Hong Kong, in line with previous theoretical analysis of expectations.

The empirical results show that industrial structure evolution is the Granger cause of industry income gap, and there is a significant relationship between the two. Industrial structure evolution of Hong Kong has had a profound impact on the income gap in the industry. The increasing proportion of service added value to GDP and output value of financing, insurance, real estate and business services in the service industry will widen the industry income gap in Hong Kong.

\section{Conclusion}

Aiming at the coexistence of Hong Kong's sustained economic growth and large income gap, this paper systematically analyzes the influence mechanism of industrial structure evolution on the industry income gap in Hong Kong. This paper reveals the transmission mechanism of industrial structure, employment structure and industry income gap in Hong Kong, and empirically verifies the causal relationship between service-oriented of industrial structure, specialization within the service industry and industry income gap in Hong Kong, and the quantitative relationship between them is further discussed by regression analysis. The results show that the industrial structure affects the income gap of the industry by influencing the employment structure. The industrial structure that tends to be service-oriented and the internal specialization of the service industry lead to the transfer of employment from the manufacturing industry with a relatively low Theil index to the service industry, especially financing, insurance, real estate and business services, which are relatively high in the Theil index. As a result, the overall industry income Theil index is rising, and the industry income gap is widening in Hong Kong.

\section{References}

[1] World Economic Forum (2017) The Global Competitiveness Report 2017-2018. https://www.weforum.org/reports/the-global-competitiveness-report-2017-2018

[2] Liu, G.F. (2006) The Evolution and Outlet of Hong Kong's Industrial Structure. Special Zone Economy, No. 3, 65-67.

[3] Feng, B.Y. (2015) The Third Transformation of Industrial Structure in Hong Kong: Constructing a " $1+3$ " Industrial System. Hong Kong and Macao Journal, No. 4, $38-46+95$.

[4] Guo, J. and Zhao, J.Y. (2016) A Study on the Economic Development of Hong Kong from the Perspective of Industrial Structure. Reform \& Openning, No. 12, 17-18.

[5] Zhang, Y.W. (2007) Hong Kong' Economy Retrospect and Prospect. International Economics and Trade Research, 11, 18-23.

[6] Chen, G.H. and Zhang, Y.W. (2009) Economic Transformation and Income Distri- 
bution in Hong Kong. Studies on Hong Kong and Macao, No. 1, 15-27.

[7] Gan, H.M. (2012) Can Economic Growth Bring Common Prosperity: Research Based on the Distribution of Income in Hong Kong. Special Zone Economy, No. 5, 13-15.

[8] Guan, H.L. (2014) Interpretation of Industrial Structure Transformation and Income Distribution in Hong Kong. Academic Research, No. 11, 90-96.

[9] Zhang, C. (2016) Summary of Study on Relationship between Industrial Structure and Employment Structure. Journal of Huizhou University (Social Science Edition), $36,42-46+58$.

[10] Browning, H.L. and Singelmann, J. (1975) The Emergence of a Service Society: Demographic and Sociological Aspects of the Sectoral Transformation of the Labor Force in the U.S.A. National Technical Information Service, Springfield, Virginia.

[11] Singelmann, J. (1978) From Agriculture to Services: The Transformation of Industrial Employment. Sage Publications, Beverly Hills.

[12] Shang, Y.L., Shen, Y.M. and Qiu, L. (2008) The Primary Study on Industry Definition and Classification of Producer Services in China. Journal of Capital Normal University (Natural Science Edition), No. 3, 87-94.

[13] Xia, H. (2007) Theil Index and Its Application in the Industry Income Gap in China. Productivity Research, No. 7, 10-11.

[14] Liang, S.H. and Peng, D.Y. (2017) Research into the Mechanism of Industrial Structure's Impact on Industrial Income Gap. Wuhan University of Technology (Social Science Edition), No. 2, 16-23. 